1992

\title{
Transmission of Human Immunodeficiency Virus Type 1 from a Seronegative Organ and Tissue Donor
}

\section{R.J. Simonds, M.D.}

National Center for Infectious Diseases

Scott D. Holmberg M.D., M.P.H.

National Center for Infectious Diseases

Richard L. Hurwitz, M.D.

Lifenet Transplant Services

See next page for additional authors

Follow this and additional works at: http://scholarscompass.vcu.edu/hadm_pubs

Part of the Health and Medical Administration Commons

From The New England Journal of Medicine, Simonds, R.J., Holmberg, S.D., Hurwitz, R.L., et al., Transmission of Human Immunodeficiency Virus Type 1 from a Seronegative Organ and Tissue Donor, Vol. 326, Page 726, Copyright (C) 1992 Massachusetts Medical Society. Reprinted with permission.

\section{Downloaded from}

http://scholarscompass.vcu.edu/hadm_pubs/4

This Article is brought to you for free and open access by the Dept. of Health Administration at VCU Scholars Compass. It has been accepted for inclusion in Health Administration Publications by an authorized administrator of VCU Scholars Compass. For more information, please contact libcompass@vcu.edu. 


\section{Authors}

R.J. Simonds , M.D.; Scott D. Holmberg M.D., M.P.H.; Richard L. Hurwitz , M.D.; Theresa R. Coleman , B.A.; Scott Bottenfield , R.N.; Lois J. Conley, M.T., M.P.H.; Sherry H. Kohlenberg , M.H.A.; Kenneth G. Castro , M.D.; Beverley A. Dahan , B.A.; Charles A. Schable , M.S.; Mark A. Rayfield , Ph.D.; and Martha F. Rogers , M.D. 


\title{
TRANSMISSION OF HUMAN IMMUNODEFICIENCY VIRUS TYPE 1 FROM A SERONEGATIVE ORGAN AND TISSUE DONOR
}

\author{
R.J. Simonds, M.D., Scott D. Holmberg, M.D., M.P.H., Richard L. Hurwitz, M.D., \\ Theresa R. Coleman, B.A., Scott Bottenfield, R.N., Lois J. Conley, M.T., M.P.H., \\ Sherry H. Kohlenberg, M.H.A., Kenneth G. Castro, M.D., Beverley A. Dahan, B.A., \\ Charles A. Schable, M.S., Mark A. Rayfield, Ph.D., and Martha F. Rogers, M.D.
}

\begin{abstract}
Background. Since 1985, donors of organs or tissues for transplantation in the United States have been screened for human immunodeficiency virus type 1 (HIV-1), and more than 60,000 organs and 1 million tissues have been transplanted. We describe a case of transmission of HIV-1 by transplantation of organs and tissues procured between the time the donor became infected and the appearance of antibodies. The donor was a 22-year-old man who died 32 hours after a gunshot wound; he had no known risk factors for HIV-1 infection and was seronegative.
\end{abstract}

Methods. We reviewed the processing and distribution of all the transplanted organs and tissues, reviewed the medical histories of the donor and HIV-1-infected recipients, tested stored donor lymphocytes for HIV-1 by viral culture and the polymerase chain reaction, and tested stored serum samples from four organ recipients for HIV-1 antigen and antibody.

Results. HIV-1 was detected in cultured lymphocytes from the donor. Of 58 tissues and organs obtained from the donor, 52 could be accounted for by the hospitals

T HE transmission of human immunodeficiency virus type 1 (HIV-1) by the transplantation of organs and tissues has been reported infrequently, and in most cases has involved donors whose serum had not been tested for HIV-l antibody. ${ }^{1-13}$ It has been recommended since 1985 that donors of blood, organs, tissues, and semen be routinely screened for HIV-1 antibody. ${ }^{14,15}$ However, HIV-1 is still transmitted in rare cases by recently $\mathrm{HIV}-1$-infected but seronegative blood donors, ${ }^{16}$ and it is presumed that HIV-1 transmission by seronegative donors of organs or tissues might also occur. In 1991, a woman whose only risk factor for HIV-1 infection was the receipt of a bone allograft in December 1985 was identified by the health department in her state as being infected. Subsequent investigation revealed that the donor was a 22-year-old HIV-1-seronegative man who died after being shot in the head in October 1985, that 4 solid organs and 54 other tissues had been distributed from the donor, and that a total of seven of the recipients were infected with $\mathrm{HIV}-1$. In this article, we describe

From the Division of HIV/AIDS, National Center for Infectious Diseases, Centers for Disease Control, Atlanta (R.J.S., S.D.H., T.R.C., L.J.C., K.G.C., C.A.S., M.A.R., M.F.R.); Lifenet Transplant Services, Virginia Beach, Va. (R.L.H., S.B.); the Virginia Department of Health, Richmond (T.R.C.); Virginia Commonwealth University, Medical College of Virginia Hospitals, Richmond (S.H.K.); and the Colorado Department of Health, Denver (B.A.D.). Address reprint requests to Dr. Simonds at the Division of HIV/AIDS, Centers for Disease Control, 1600 Clifton Rd., MS E-45, Atlanta, GA 30333.

The use of trade names is for identification only and does not imply endorsement by the Public Health Service or the U.S. Department of Health and Human Services. that received them. Of the 48 identified recipients, 41 were tested for HIV-1 antibody. All four recipients of organs and all three recipients of unprocessed freshfrozen bone were infected with HIV-1. However, 34 recipients of other tissues -2 receiving corneas, 3 receiving lyophilized soft tissue, 25 receiving ethanol-treated bone, 3 receiving dura mater treated with gamma radiation, and 1 receiving marrow-evacuated, fresh-frozen bone - tested negative for HIV-1 antibody. Despite immunosuppressive chemotherapy, HIV-1 antibody appeared between 26 and 54 days after transplantation in the three organ recipients who survived more than 4 weeks.

Conclusions. Although rare, transmission of HIV-1 by seronegative organ and tissue donors can occur. Improvements in the methods used to screen donors for HIV-1, advances in techniques of virus inactivation, prompt reporting of HIV infection in recipients, and accurate accounting of distributed allografts would help to reduce further this already exceedingly low risk. ( $N$ Engl $\mathrm{J}$ Med 1992;326:726-32.)

our investigation, provide evidence of HIV-1 infection in the seronegative donor and seven recipients of unprocessed organs or tissues, and document the absence of transmission of HIV-l to recipients of other tissues processed in various ways. We also attempt to identify gaps in the reporting and tracking of adverse events surrounding transplantation, such as HIV infection, and suggest ways of further reducing the already low risk of HIV transmission by transplantation.

\section{Methods}

We contacted representatives from each hospital that received organs or tissues from the donor and asked them to locate the transplant recipients and offer them testing and counseling for HIV. We collected clinical information about the recipients with HIV-1 infection through reviews of medical records or discussions with the recipients' physicians or local health departments.

To search for additional cases of the acquired immunodeficiency syndrome (AIDS) associated with transplantation, we reviewed cases of AIDS reported to the Centers for Disease Control (CDC) from 1982 through November 1991 and investigated case reports containing references to transplantation.

\section{Laboratory Investigations}

We tested frozen spleen cells from the donor for HIV-1 by culture and the polymerase chain reaction (PCR) at the CDC. We cocultivated the donor's cells with phytohemagglutinin-stimulated normal peripheral-blood mononuclear cells and analyzed the supernatant for HIV-1 core antigen with a commercial kit (Genetic Systems, Seattle), for HIV-1 proviral DNA by PCR analysis, and for reverse transcriptase activity every three days for one month. The conditions for viral culture and assay have been described previously. ${ }^{17-19}$

Serum specimens obtained from each of the four organ recipients 
before and after transplantation had been stored at the tissue-typing laboratory of the hospital where transplantation had been performed. We tested these specimens for HIV-1 p24 antigen at the CDC, using a commercial enzyme immunoassay kit (Dupont, Wilmington, Del.). All reactive specimens were verified by neutralization. We also used an enzyme immunoassay (Organon-Teknika, Durham, N.C.) and Western blot analysis (Ortho, Raritan, N.J.) to test the specimens for HIV-1 antibody.

\section{Epidemiologic Investigations}

We reviewed the donor's medical records, the events surrounding his death, the details of organ and tissue procurement, and the results of HIV-1 testing. We interviewed his family and friends about his possible risk factors for HIV-1 infection. We also tested serum samples from several female sexual partners for HIV-1 antibody.

\section{Preparation of Organs and Tissue}

The heart, liver, and kidneys were removed from the donor, preserved by rapid cooling, and maintained in a crystalloid solution at $4^{\circ} \mathrm{C}$ until transplantation. All organs were transplanted within 24 hours of their removal. Four pieces of bone (two femoral heads, a patella, and a proximal femur) were fresh-frozen, 4 pieces of soft tissue were lyophilized, 38 pieces of bone were lyophilized and treated with ethanol, and 6 pieces of dura mater were lyophilized and irradiated. Tissue that was lyophilized had extraneous soft tissues removed; this was followed by treatment with bacitracin and polymyxin $B$ sulfate, irrigation with sterile water, packaging, refreezing to $-80^{\circ} \mathrm{C}$, and lyophilization to a residual moisture content of less than 5 percent. Tissue that was treated with ethanol underwent ultrasonic cleaning in 30 percent ethanol, removal of marrow elements by pulsating water lavage, and brief treatment in 100 percent ethanol. Tissue that was irradiated received 3.0 to 3.4 Mrad of gamma radiation through a cobalt -60 source. The corneas were suspended in a dextrose-electrolyte-gentamicin solution. A total of 35 centers received organs, tissues, or both for transplantation.

\section{Results}

\section{Donor}

The donor was not known to have any risk factors for HIV-1 infection, and two serum specimens tested negative for HIV-1 antibody on enzyme immunoassay at the time of organ procurement. The optical density of one specimen was 0.015 in an assay in which the cutoff value indicating a positive sample was 0.175 (Abbott Laboratories, North Chicago); the other specimen was only recorded as "negative." Because hemodilution may occur if many infusions or transfusions are given just before an $\mathrm{HIV}-1$ antibody test and may lead to a false negative result, ${ }^{1}$ the donor's fluid intake and output were reviewed; there was no substantial net gain of fluids before the blood samples were drawn. Serologic tests for hepatitis A antibody, syphilis, and hepatitis B surface antigen, surface antibody, and core antibody were negative. The donor received two units of plasma protein fraction, but no other blood products, after his injury. Although it is not known whether the plasma donors had been screened for HIV-1 antibody, the blood bank that supplied the plasma protein fraction confirmed that the lots from which the units were obtained had not been implicated in other cases of HIV-1 transmission.

Reviews of medical records and interviews with the donor's family members and sexual partners during this investigation did not reveal that the donor had any other risk factors for HIV-l infection, such as sexual contact with other men, receipt of blood transfusions, intravenous drug use, or sexual contact with women who were intravenous drug users, transfusion recipients, or sexual partners of men with any of the above risk factors. Two women who had been sexual partners of the donor in the six months before his death and three other friends (one man and two women) were interviewed; serum specimens from each of them tested negative for HIV-1 antibody. One other female sexual partner declined to be interviewed or to provide serum for HIV-1-antibody testing.

The presence of HIV-1 in the cultured spleen tissue from the donor was established by the detection of

Table 1. Dates of Transplantation, HIV Risk Factors, Antirejection Therapy, and Outcomes in Seven HIV-1-Infected Recipients of Organs or Tissues from a Seronegative Donor.

\begin{tabular}{|c|c|c|c|c|c|c|}
\hline $\begin{array}{l}\text { Organ Or Tissue } \\
\text { TransPlanted }\end{array}$ & $\begin{array}{l}\text { Date OF TRANS- } \\
\text { PLANTATION }\end{array}$ & $\begin{array}{l}\text { OTHER HIV } \\
\text { RISK FACTOR* }\end{array}$ & $\begin{array}{l}\text { ANTIREJECTION } \\
\text { THERAPY }\end{array}$ & $\begin{array}{l}\text { Follow-UP } \\
\text { TIME }\end{array}$ & OUtсоме & $\begin{array}{l}\text { DATE HIV-I } \\
\text { INFECTION } \\
\text { DIAGNOSED }\end{array}$ \\
\hline Heart & $10 / 85$ & Transfusion & Cyclosporine, azathioprine & $9 \mathrm{mo}$ & Death & $6 / 86 \dagger$ \\
\hline Liver & $10 / 85$ & Transfusion $\ddagger$ & $\begin{array}{l}\text { Cyclosporine, prednisone or methyl- } \\
\text { prednisolone, antithymocyte } \\
\text { globulin, OKT3§ }\end{array}$ & 24 days & Death & $5 / 919$ \\
\hline Left kidney & $10 / 85$ & Transfusion $\ddagger$ & $\begin{array}{l}\text { Cyclosporine, prednisone or methyl- } \\
\text { prednisolone }\end{array}$ & $32 \mathrm{mo}$ & Death & $3 / 87$ \\
\hline Right kidney & $10 / 85$ & Transfusion & $\begin{array}{l}\text { Prednisone or methylprednisolone, } \\
\text { azathioprine }\end{array}$ & $14 \mathrm{mo}$ & Death & $5 / 86$ \\
\hline Femoral head & $12 / 85$ & None & None & $6 \mathrm{yr}$ & Alive & $12 / 87$ \\
\hline Femoral head & $12 / 85$ & Transfusion & None & $5 \mathrm{yr}$ & Death & 1987 \\
\hline Patella & $1 / 86$ & None & None & $6 \mathrm{yr}$ & Alive & $5 / 91$ \\
\hline
\end{tabular}


reverse transcriptase, HIV-1 p24 antigen, and HIV-1 proviral DNA by PCR.

\section{Organ Recipients}

All four organ recipients became infected with HIV-1 after transplantation. Table 1 summarizes the dates of transplantation, antirejection therapy, and follow-up information for the HIV-1-infected recipients.

The donor's heart was transplanted into a 55-yearold man with accelerated coronary vascular disease whose previous heart allograft had been immunologically rejected. Between six and eight months after transplantation, herpes zoster, thrush, Pneumocystis carinii pneumonia, and cytomegalovirus retinitis and cerebritis developed. Because his illness suggested a degree of immunosuppression out of proportion to that expected from the antirejection chemotherapy he had received, the recipient was evaluated for HIV-1 infection. Two serum specimens collected eight months after transplantation were positive for HIV-1 antibody on enzyme immunoassay, but negative on Western blotting. The cerebritis progressed, and the patient died in August 1986. Because there was an alternative cause of immunosuppression and a negative Western blot assay, this case did not meet the criteria for the AIDS case definition then. The HIV-1 infection was confirmed in 1991 by the detection of HIV-l antibody and p24 antigen in stored serum (Fig. 1), at which time the case was reported to the state health department and the CDC as a case of AIDS.

The liver was transplanted into a 26-year-old man with liver failure due to sclerosing cholangitis. Immunologic rejection was diagnosed two weeks after transplantation. The patient was not evaluated for HIV-1 infection before he died of hepatic and renal failure 24 days after transplantation; however, HIV-1 p24 antigen was detected in stored serum samples obtained after transplantation and tested in 1991 (Fig. 1).

The left kidney was transplanted into a 45-year-old
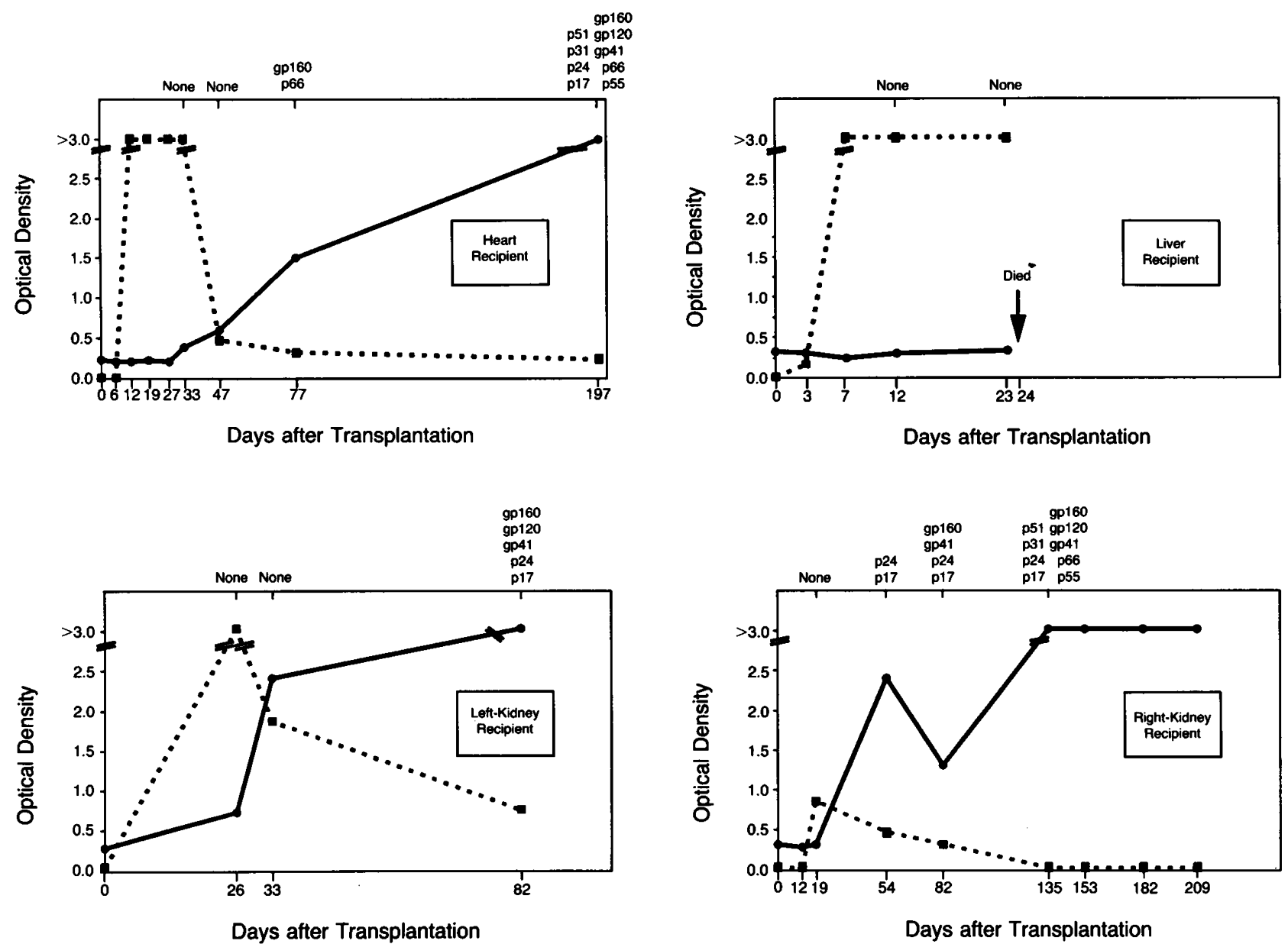

Figure 1. Results of Enzyme Immunoassays for p24 Antigen (Dotted Lines) and HIV-1 Antibody (Solid Lines) and Western Blot Assays of Stored Serum from Recipients of Transplanted Organs from a Seronegative Donor.

Bands detected by the Western blot assay at various dates after transplantation are shown at the top of each figure. For the HIV-1-antibody test, an optical density of 0.48 was considered positive. For the p24 antigen test, an optical density of 0.08 was considered positive. 
man with end-stage renal disease. Progressive dementia developed shortly after transplantation. The patient was evaluated because of an exacerbation of dementia 17 months after transplantation, and a serum sample tested positive for HIV-l antibody. One month later his CD4+ T-lymphocyte count was $0.108 \times 10^{9}$ cells per liter. Because an investigation verified the kidney donor's negative HIV-1-antibody tests, it was then concluded that the recipient had been infected with HIV-1 by one of his many previous blood transfusions. He died of cytomegalovirus pneumonia in June 1988. The case was reported as a case of AIDS to the state health department and the CDC in December 1988, with HIV-1 infection attributed to receipt of blood transfusions.

The right kidney was transplanted into a 34-yearold man with end-stage renal disease. Shortly after transplantation, the kidney was immunologically rejected. The patient resumed hemodialysis, and a serum specimen obtained routinely at the hemodialysis center was positive for HIV-l antibody seven months after transplantation. Transmission of HIV-1 infection to this recipient was attributed to the receipt of blood transfusions before 1985. Cardiomyopathy and chronic pancreatitis developed before the patient died of renal failure in December 1986. Although his CD4+ count was $0.360 \times 10^{9}$ cells per liter shortly before his death, he did not have AIDS, and consequently this case was not reported to the state health department or the CDC.

No HIV-1 antigen or antibody was detected in stored serum samples taken from any of the organ recipients before transplantation (Fig. 1). In all four recipients, HIV-1 antigen first appeared in specimens obtained between 3 and 26 days after transplantation. In the heart and kidney recipients, HIV-1 antibody first appeared in specimens obtained between 26 and 54 days after transplantation. In the liver recipient, no HIV-l antibody was detectable in specimens taken before the patient's death 24 days after transplantation.

\section{Tissue Recipients}

\section{Fresh-Frozen Bone}

Three of the four recipients of fresh-frozen bone became infected with HIV-1. One died and three were alive at the most recent follow-up (Table 1).

A 72-year-old woman received one of the femoral heads during a hip-replacement procedure in December 1985. In 1987, because of a mistaken assumption that she had received a heterologous blood transfusion during the procedure, she had her serum tested for HIV-1 antibody. The specimen was positive on enzyme immunoassay and Western blotting. In 1991, during a routine review of 1990 hospital discharges, the patient was identified by the state health department as being infected with HIV-1. After several interviews, no risk factors for HIV-l infection other than receipt of the allograft were identified. In April 1991 the health department notified the tissue-procurement organization, the health department in the state from which the tissue donation originated, and the GDC, and an investigation of the other organ and tissue recipients was initiated. As of December 1991, the patient had no symptoms of HIV-1 infection; her CD4+ count was $0.404 \times 10^{9}$ cells per liter in September 1991 .

The other femoral head was transplanted into a 77year-old woman during a knee-replacement procedure in December 1985. She had received blood transfusions before 1985 and tested positive for HIV-1 antibody in 1987. Her CD4+ count was $0.316 \times 10^{9}$ cells per liter in September 1989, after which she was treated intermittently with zidovudine and didanosine. In December 1990, her CD4+ count was $0.024 \times 10^{9}$ cells per liter, and oropharyngeal candidiasis developed. The patient died in August 1991 of aspiration pneumonia.

A man in his 30 s received the patella (including the patellar ligament and tendon and a section of tibia) in January 1986 and had an episode of fever, rash, pharyngitis, and lymphopenia consistent with an acute retroviral syndrome three weeks later. He was first evaluated for HIV-1 infection during this investigation, when his serum was positive for HIV-1 antibody. His CD4+ count was $0.562 \times 10^{9}$ cells per liter in May 1991; at the most recent follow-up, in December 1991, he had no symptoms of HIV-1 infection.

A 69-year-old man received the proximal femoral shaft as part of a total hip revision. Unlike the other fresh-frozen bone pieces, the canal of this allograft was extensively excavated to permit the insertion of a metal rod. The excavation probably removed all marrow elements from the bone before implantation. This recipient's serum tested negative for HIV-1 antibody.

\section{Other Tissues}

Fifty other pieces of donor tissue that had been processed in various ways were distributed for transplantation (Table 2). Forty patients who received 42 of these allografts have been identified, and serum samples from 33 recipients were tested for HIV-1 antibody. All were negative. Of the seven untested recipients, three died of unrelated causes, three were identified but not located, and one was located but not tested for HIV-1 antibody. Of the eight pieces of tissue not traced to recipients, one piece had been destroyed before transplantation by the receiving hospital, one piece was impounded by the tissue bank during this investigation, and six pieces could not be accurately accounted for by the six hospitals that received them.

\section{Investigation of AIDS Case Surveillance}

Information about the receipt of transplanted organs or tissues has not been routinely collected in national AIDS surveillance case reports, but it is sometimes included in additional written comments. Reference to transplantation was found in 33 reports. Of these, two were reports of patients described in this investigation (the recipients of the left kidney and 
the heart), and three others correspond to cases that have been described elsewhere. ${ }^{1-3}$ Among the 28 remaining reports, the following risk factors for HIV infection other than transplantation were identified: receipt of unscreened blood transfusions in 18 cases, homosexual or bisexual contact with men in 8 cases, treatment for hemophilia in 1 case, and heterosexual contact with an HIV-infected person in 1 case.

\section{Discussion}

Cases of HIV-1 transmission by transplantation of kidney, ${ }^{1-9}$ liver, ${ }^{1,10}$ heart, ${ }^{3,11}$ pancreas, ${ }^{3}$ bone, ${ }^{12}$ and possibly skin ${ }^{13}$ allografts from HIV-1-infected donors have been reported. In most of the reports, transplantation was performed before 1985, when screening of blood, organ, and tissue donors for HIV-1 antibody became routine. In three reports transplantation occurred after 1985. In one, the donor's serum tested falsely negative after a massive blood transfusion caused hemodilution of HIV-1 antibody ${ }^{1}$; in the second, the donor seroconverted after having been screened eight months before transplantation $^{8}$; and in the third, urgent transplantation was performed before the result of the donor's positive HIV-1 test was available. ${ }^{10}$

The donor in this investigation probably had an early stage of HIV-1 infection, since no detectable HIV-1 antibody had developed by the time of his death. Other explanations for HIV-1 transmission from a donor testing negative for HIV-l antibody, such as hemodilution ${ }^{1}$ or perioperative transfusion of an infected blood product to the donor, ${ }^{3}$ were excluded. The only blood product he received was plasma protein fraction. The processing of this product inactivates HIV $-1 .^{20}$

There is usually a period of several weeks to six months between HIV-1 infection and the appearance of HIV-1 antibody. ${ }^{21}$ Because HIV-1 has been transmitted from blood donors with early infection in whom HIV-1 antibody had not developed by the time of screening ${ }^{16,22}$ transmission of the virus to recipients of organs and tissues from an HIV-1-infected but seronegative donor, as occurred in this case, is not unexpected. The exact risk of HIV-1 transmission from a seronegative organ or tissue donor is unknown, but is probably very small. More than 60,000 organs and 1 million tissue allografts have been transplanted in the United States since routine donor screening for antibody to HIV-1 was instituted in 1985. A review of CDC AIDS surveillance reports that mentioned transplantation did not reveal any additional cases of AIDS attributable to transplantation from HIV-1-seroneg- ative donors, although transmission by transplantation cannot be definitively excluded in most cases involving other risk factors.

Given the presence of even a small risk of transmission of HIV infection through transplantation, it is important to develop strategies for the prevention of transmission and the management of cases in which transmission has been identified. Approaches to prevention include the screening of prospective donors for risk factors and laboratory markers for HIV-1 infection, the inactivation of HIV-l in allografts through processing techniques, and the quarantining of tissues from living donors until repeat antibody testing more definitively excludes the possibility of subsequent seroconversion in the donor. Heightened donor-screening practices, however, must not result in the unnecessary exclusion of donors and a subsequent reduction in the availability of needed allografts.

Careful evaluation of a prospective donor's medical and social histories for risks associated with HIV-1 infection and the exclusion of persons found to be at high risk for infection regardless of their antibody-test results help exclude potential donors who may have been recently infected with HIV-1. However, assessment of HIV-1 risk factors in donors who are unconscious or dead is often difficult, since family members or friends may be unable to provide complete and accurate medical and social information. In the present case, neither evaluation of the donor before transplantation nor subsequent investigation in 1991 identified a source for his HIV-1 infection.

The use of HIV-1-antibody testing to screen serum from prospective organ or tissue donors has been recommended since $1985 .{ }^{15}$ Tests to detect HIV-1 before seroconversion, such as the p24 antigen assay and the 
PCR, should also be evaluated for use in donor screening. Studies of p24 antigen screening have not demonstrated improved detection of HIV-1-infected seronegative blood donors. ${ }^{23,24}$ However, because the process of HIV risk assessment and donation deferral may be less effective for cadaveric donors than for blood donors, p24 antigen may have greater usefulness for screening organ and tissue donors. Likewise, the PCR assay may be a promising test to detect early HIV-1 infection, but the procedure is technically difficult and still unlicensed.

Allograft processing that eliminates or inactivates HIV-1 may also reduce the risk of HIV-1 transmission by transplantation. The ability of heat, ethanol, other chemicals, and ultraviolet and gamma radiation to inactivate HIV-1 in plasma has been demonstrated. ${ }^{20,25,26}$ However, whether these processes can inactivate HIV-1 in allografts without affecting the functional integrity of the allografts is unknown. ${ }^{27,28}$ In our report, recipients of tissues that were avascular or processed by lyophilization, ethanol extraction, irradiation, or the mechanical removal of blood and hematogenous elements did not acquire HIV-l infection. The absence of transmission of HIV-1 to recipients of processed tissues could have been due to processing or to the fact that most of these tissues were relatively avascular and may not have contained HIV-1-infected cells. Our investigation cannot quantitate the risk of acquiring HIV-1 from these processed and avascular tissues, although it suggests that transmission is uncommon.

The risk of HIV-1 transmission from a seronegative tissue donor may also be reduced by quarantining tissue grafts until a subsequent negative HIV-1-antibody test confirms that the donor was not infected at the time of tissue removal. Such a quarantine is practical only for certain tissues from living donors that can be preserved for three to six months, and the practice has been recommended for donors of bone $\mathrm{e}^{12}$ and semen. ${ }^{29}$

In the rare instances in which HIV infection is transmitted to organ or tissue recipients, prompt identification of infected recipients allows the seizure of unused tissues obtained from the donor, the evaluation of other recipients of organs or tissues, the early referral of infected recipients for appropriate medical care, and the prevention of secondary transmission of HIV infection by infected recipients.

Our investigation highlights several reasons that the recognition of transplantation as the source of infection in HIV-infected recipients may be delayed. First, as was the case with the kidney-transplant recipients in this investigation, organ recipients often receive numerous transfusions of blood and blood products, and HIV infection may be more likely to be attributed to transfusion than to transplantation. Second, as was the case with the heart-transplant recipient, signs and symptoms of immunosuppression may be attributed to the antirejection therapy rather than to HIV infection. Finally, as was the case with the liver-transplant recipient, recipients may die of underlying conditions before HIV infection is diagnosed. To avoid such delays, those providing medical care to transplant recipients should be aware of the possibility of HIV transmission by screened donors and should promptly evaluate transplant recipients with signs or symptoms of HIV infection. Transplant recipients who become infected with HIV should be promptly reported to the organ- or tissue-procurement organization involved and, in accord with state law, to the local or state health department.

The inability of several hospitals in this investigation to track the disposition of grafts to recipients also demonstrates a need for improved record-keeping. Efficient tracking is necessary to allow the evaluation of recipients and the recall of unused grafts in the event of the discovery of an adverse outcome, such as HIV infection, after transplantation.

Finally, this case provides information about the appearance of HIV-1 antibody in persons receiving immunosuppressive therapy. Antibody was detected by enzyme immunoassay in stored specimens obtained between 26 and 54 days after transplantation in the three recipients who survived more than 4 weeks, corroborating reports that immunosuppressive medications, which primarily affect cellular immunity, do not delay this antibody response to HIV-1 infection in most cases. ${ }^{2,10,30-32}$

The Public Health Service is currently revising its guidelines for the prevention of HIV transmission by transplantation and is considering whether to expand federal regulation of organ and tissue transplantation. ${ }^{33}$ Advances in the areas highlighted in this report, in addition to decreasing the already low risk of HIV transmission by transplanted organs and tissues, may also reduce the risk of other transmissible infections and improve the tracking of other adverse outcomes after transplantation.

We are indebted to Ann King, M.D., Michael Hess, M.D., Lisa Kaplowitz, M.D., and Daniel J. Cook, Ph.D., Virginia Commonwealth University, Medical College of Virginia Hospitals, Richmond; to Troy Williams, Food and Drug Administration, Richmond, Va.; to Grayson Miller, M.D., and Jacqueline W. Adkins, R.N., Virginia State Department of Health, Richmond; to Andrew Heaton, M.D., American Red Cross, Norfolk, Va.; to Bill Anderson, Lifenet Transplant Services, Virginia Beach, Va.; to Jeanne C. Mowe, American Association of Tissue Banks, McLean, Va.; to Nancy Enyart, Donna Cecere, Melissa Billeter, Mishelle Macias, and April Montgomery, Colorado Department of Health, Denver; to Gail Maureen Hansen, Commission of Public Health of the District of Columbia, Washington, D.C.; to John C. Perkins, M.D.; to Corwin Dunn, M.D.; to Richard Swanson, Division of Epidemiology and Emergency Operations, Office of Regulatory Affairs, Food and Drug Administration, Rockville, Md.; and to Janet Brzuskiewicz, Centers for Disease Control, Atlanta.

\section{REFERENCES}

1. Human immunodeficiency virus infection transmitted from an organ donor screened for HIV antibody - North Carolina. MMWR 1987;36:3068.

2. Kumar P, Pearson JE, Martin DH, et al. Transmission of human immunodeficiency virus by transplantation of a renal allograft, with development of the acquired immunodeficiency syndrome. Ann Intern Med 1987;106:2445 . 
3. Erice A, Rhame FS, Heussner RC, Dunn DL, Balfour HH Jr. Human immunodeficiency virus infection in patients with solid-organ transplants: report of five cases and review. Rev Infect Dis 1991;13:537-47.

4. Schwarz A, Hoffmann F, L'age-Stehr J, Tegzess AM, Offermann G. Human immunodeficiency virus transmission by organ donation: outcome in cornea and kidney recipients. Transplantation 1987;44:21-4.

5. Prompt CA, Reis MM, Grillo FM, et al. Transmission of AIDS virus at renal transplantation. Lancet 1985;2:672.

6. L'age-Stehr J, Schwarz A, Offermann G, et al. HTLV-III infection in kidney transplant recipients. Lancet 1985;2:1361-2.

7. Neumayer HH, Fassbinder W, Kresse S, Wagner K. Human T-lymphotropic virus III antibody screening in kidney transplant recipients and patients receiving maintenance hemodialysis. Transplant Proc 1987;19:2169-71.

8. Quarto M, Germinario C, Fontana A, Barbuti S. HIV transmission through kidney transplantation from a living related donor. N Engl J Med 1989;320: 1754.

9. Carbone LG, Cohen DJ, Hardy MA, Benvenisty AI, Scully BE, Appel GB Determination of acquired immunodeficiency syndrome (AIDS) after renal transplantation. Am J Kidney Dis 1988;11:387-92.

10. Samuel D, Castaing D, Adam R, et al. Fatal acute HIV infection with aplastic anaemia, transmitted by liver graft. Lancet 1988;1:1221-2.

11. Dummer JS, Erb S, Breinig MK, et al. Infection with human immunodeficiency virus in the Pittsburgh transplant population: a study of 583 donors and 1043 recipients, 1981-1986. Transplantation 1989;47:134-40.

12. Transmission of HIV through bone transplantation: case report and public health recommendations. MMWR 1988;37:597-9.

13. Clarke JA. HIV transmission and skin grafts. Lancet $1987 ; 1: 983$.

14. Provisional Public Health Service inter-agency recommendations for screening donated blood and plasma for antibody to the virus causing acquired immunodeficiency syndrome. MMWR 1985;34:1-5.

15. Testing donors of organs, tissues, and semen for antibody to human T-lymphotropic virus type III/lymphadenopathy-associated virus. MMWR 1985;34:294.

16. Ward JW, Holmberg SD, Allen JR, et al. Transmission of human immunodeficiency virus (HIV) by blood transfusions screened as negative for HIV antibody. N Engl J Med 1988;318:473-8.

17. Feorino P, Forrester B, Schable C, Warfield D, Schochetman G. Comparison of antigen assay and reverse transcriptase assay for detecting human immunodeficiency virus in culture. J Clin Microbiol 1987;25:2344-6.

18. Jackson J. Human immunodeficiency virus type 1 antigen and culture assays. Arch Pathol Lab Med 1990;1 14:249-53.
19. Pieniazek D, Peralta JM, Ferreira JA, et al. Identification of mixed HIV-1/HIV-2 infections in Brazil by polymerase chain reaction. AIDS 1991;5:1293-9.

20. Hilfenhaus JW, Gregersen JP, Mehdi S, Volk R. Inactivation of HIV-1 and HIV-2 by various manufacturing procedures for human plasma proteins Cancer Detect Prev 1990;14:369-75.

21. Horsburgh CR Jr, Ou CY, Jason J, et al. Duration of human immunodeficiency virus infection before detection of antibody. Lancet 1989;2:63740.

22. Busch MP, Eble BE, Khayam-Bashi H, et al. Evaluation of screened blood donations for human immunodeficiency virus type 1 infection by culture and DNA amplification of pooled cells. N Engl J Med 1991;325:1-5.

23. Alter HJ, Epstein JS, Swenson SG, et al. Prevalence of human immunodeficiency virus type 1 p24 antigen in U.S. blood donors - an assessment of the efficacy of testing in donor screening. N Engl J Med 1990;323:1312-7.

24. Busch MP, Taylor PE, Lenes BA, et al. Screening of selected male blood donors for p24 antigen of human immunodeficiency virus type 1. N Engl J Med 1990;323:1308-12.

25. Kitchen AD, Mann GF, Harrison JF, Zuckerman AJ. Effect of gamma irradiation on the human immunodeficiency virus and human coagulation proteins. Vox Sang 1989;56:223-9.

26. Wells MA, Wittek AE, Epstein JS, et al. Inactivation and partition of human T-cell lymphotrophic virus, type III, during ethanol fractionation of plasma. Transfusion 1986;26:210-3.

27. Buck BE, Resnick L, Shah SM, Malinin TI. Human immunodeficiency virus cultured from bone: implications for transplantation. Clin Orthop 1990;251:249-53.

28. Conway B, Tomford W, Mankin HJ, Hirsch MS, Schooley RT. Radiosensitivity of HIV-1 - potential application to sterilization of bone allografts. AIDS 1991;5:608-9.

29. Semen banking, organ and tissue transplantation, and HIV antibody testing. MMWR 1988;37:57-8, 63

30. Rubin RH, Tolkoff-Rubin NE. The problem of human immunodeficiency virus (HIV) infection and transplantation. Transpl Int 1988;1:36-42.

31. Schirm J, Drenth J, Van den Akker R, et al. Rapid HIV seroconversion after kidney transplantation. Serodiagn Immunother Infect Dis 1988;2:91-3.

32. Ward JW, Schable C, Dickinson GM, et al. Acute human immunodeficiency virus infection: antigen detection and seroconversion in immunosuppressed patients. Transplantation 1989;47:722-4.

33. Food and Drug Administration. Human organ and tissue transplantation public hearing. Fed Regist 1991;56:43026-8. 